\title{
PENINGKATAN KEMAMPUAN GURU DALAM MELAKUKAN PENILAIAN RANAH SIKAP MELALUI IN HOUSE TRAINING
}

\author{
Oleh: Rustini Rahayu \\ SD N Canden Jetis Bantul \\ Email: rustinirahayu@ymail.com
}

\begin{abstract}
The objectives of this study were (1) to apply in-house training among teachers in assessing the attitude aspect, and (2) to improve the teacher ability to conduct an attitude assessment through an in-house training model. This study was a school action research (PTS). The study method conducted in two cycles, carried out at SD N Canden, Bantul Regency at 2017/2018 Academic Year. The data was obtained through observation and documentation. The results of each cycle were analyzed using descriptive approach, and then used as reference for the next action. The teacher's ability with the capable category has reached $80 \%$. The results of this study reveal that trainers ability to implement in-house training in the cycle I was in high category (60\%) and has increased to $100 \%$ in cycle II. The in-house training model was able to improve the teacher ability to assess the attitude aspect. This was demonstrated by the increase of teacher ability from capable category (50\%) in the cycle I to be a very capable (70\%) and capable (30\%) category in the cycle II. The in-house training may improve the teacher's ability to conduct an assessment of the attitude aspect as well.
\end{abstract}

Keywords: teacher's ability, attitude assessment, in-house training (IHT)

\section{PENDAHULUAN}

Penilaian hasil belajar akan dapat meningkatkan kualitas proses dan hasil pembelajaran. Sulistyawardani dkk (2012: 94) menyatakan bahwa keberhasilan seseorang dipengaruhi oleh kondisi afeksinya. Seseorang dengan kemampuan afektif yang buruk tentu akan kesulitan mencapai keberhasilan belajar yang optimal. Oleh karena itu, tenaga pendidik harus memberikan perhatian yang serius menyangkut pengembangan penilaian ranah afektif peserta didik. Sesuai Depdiknas pada Peraturan Pemerintah nomor 32 tahun 2013 tentang Standar Nasional Pendidikan, bahwa penilaian afektif menjadi satu komponen penilaian penting yang harus dilakukan oleh pendidik, dalam hal ini adalah guru.

Seorang guru mempengaruhi prestasi siswa, salah satunya pada pengukuran efikasi diri siswa, dan perilaku siswa di kelas. Sikap dan perilaku siswa diprediksi dengan mengajarkan praktik paling proksimal, termasuk dukungan emosional guru dan organisasi kelas. Namun, guru yang efektif dalam meningkatkan nilai ujian sering tidak sama efektifnya dalam meningkatkan sikap dan perilaku siswa (Blazar dan Kraft, 2017:1).

Kemampuan guru saat ini dalam melakukan penilaian sikap terhadap peserta didik cenderung kurang. Hal tersebut dikarenakan guru terlalu fokus memberikan penilaian berdasarkan aspek kognitif dan mengesampingkan penilaian sikap. Guru merasa bahwa pengukuran ranah afektif tidaklah semudah mengukur ranah kognitif, dimana pengukuran ranah afektif tidak dapat dilakukan setiap saat karena perubahan tingkah laku siswa sewaktu-waktu. Selain itu, perubahan sikap seseorang memerlukan waktu yang reatif lama, perbuatan secara fisik adalah suatu bentuk tingkah laku yang mudah dilihat dan dapat diukur.

Penelitian Astuti, dkk (2017: 13) dengan melibatkan 13 guru SD Laboratorium Satya Wacana menunjukkan temuan berikut: 1) Hanya $31 \%$ guru yang telah melakukan penilaian mencakup tiga ranah (kognitif, afektif, dan psikomotor); 2) Hanya 31\% guru yang melakukan penilaian non tes jenis skala sikap untuk mengukur sikap siswa; 3) Hanya $23 \%$ guru yang memiliki pemahaman yang 
cukup untuk mengembangkan penilaian sikap; dan 4) Hanya $15 \%$ guru yang memiliki pemahaman yang cukup untuk mengembangkan instrument penilaian skala sikap model Likert.

Kemampuan guru yang baik akan mendorong guru melakukan perilaku kognitif, afektif dan psikomotorik dengan sebaikbaiknya. Sejalan dengan ungkapan Mulyasa dalam Astuti, dkk (2017: 39) bahwa kompetensi guru sebagai penguasaan terhadap suatu tugas, keterampilan, sikap, dan apresiasi diperlukan untuk menunjang keberhasilan.

Pengamatan Alufohai et al (2016: 72) menunjukkan sebagian besar guru di sekolah Negara Bagian Nigeria tidak mau melakukan beberapa praktik penilaian berkelanjutan seperti perencanaan: waktu untuk menilai siswa; jenis alat tes yang digunakan; area domain pembelajaran untuk dinilai; penggunaan teknik scoring; cara menilai kemajuan siswa secara keseluruhan berdasarkan pada domain kognitif, afektif, dan psikomotor mereka. Sementara sejumlah guru memiliki pengetahuan tentang kebutuhan untuk melakukan praktik ini; beberapa menganggapnya tugas yang melelahkan dan tidak menarik. Akibatnya, beberapa dari mereka menghindar dari melakukan berbagai praktik yang terlibat.

Berdasarkan urain tersebut, nampak bahwa terdapat kesenjangan antara praktik penilaian yang ideal dengan kenyataan yang terjadi. Kesenjangan tersebut merupakan kebutuhan yang harus dipenuhi melalui tindakan pelatihan. Untuk mewujudkan guru yang profesional perlu adanya program dan kegiatan yang mengarah pada peningkatan mutu Guru dengan mengikutsertakan pelatihan,salah satunya melalui In House Training penyusunan penilaian ranah sikap.

In House Training (IHT) merupakan program pelatihan yang dilaksanakan secara internal oleh kelompok kerja guru, sekolah atau tempat lain yang dilakukan berdasarkan pada pemikiran bahwa sebagian kemampuan dalam meningkatkan kompetensi guru tidak harus dilakukan secara eksternal, namun dapat dilakukan secara internal dengan batasan peserta minimal 4 orang dan maksimal 15 orang (Danim, 2011: 94).

Adanya In-House Training dapat digunakan untuk meningkatkan kualitas sumberdaya manusia, sehingga pada akhirnya dapat lebih mendukung dalam pencapaian sasaran yang telah ditetapkan. Sasaran pelatihan internal ini antara lain: menciptakan interaksi, mempererat rasa kebersamaan, meningkatkan motivasi, mengeksplorasi permasalahan di lapangan yang berkaitan dengan efektifitas kerja, sehingga dapat diformulasikan solusi pemecahannya secara bersama (Dasman, 2016: 89).

Penelitian Suhandi Astuti (2016: 6) menunjukkan pelatihan model In House Training dapat meningkatkan kemampuan guru dalam menyusun instrument penilaian ranah sikap. Kontribusi penelitian ini secara teoritis memantapkan langkah penyusunan skala sikap model Likert, dan secara praktek meningkatkan kemampuan guru dalam menyusun instrumen penilaian ranah sikap dalam pembelajaran.

Peneliti tertarik melakukan penelitian dengan judul "Peningkatan Kemampuan Guru Dalam Penyusunan Instrumen Penilaian Ranah Sikap Melalui In House Training di SD N Canden Tahun Pelajaran 2018/2019”.

Berdasarkan uraian di atas dapat dirumuskan permasalahan sebagai berikut:

1. Bagaimana kemampuan guru dalam melakukan penilaian ranah sikap?

2. Bagaimana penerapan in house training dalam meningkatkan kemampuan guru melakukan penilaian ranah sikap?

Tujuan dari penelitian ini yaitu untuk meningkatkan kemampuan guru dalam melakukan penilaian ranah sikap melalui in house training di SD $\mathrm{N}$ Canden Tahun Pelajaran 2017/2018.

Sedangkan tujuan khusus dalam penelitian ini yaitu: 
1. Menerapkan in house training kepada guru dalam melakukan penilaian ranah sikap

2. Meningkatkan kemampuan guru dalam melakukan penilaian ranah sikap melalui model in house training

\section{Kemampuan Guru}

Merupakan kecerdasan yang dimiliki guru baik dari segi pengetahuan maupun perilaku ketika berinteraksi dengan semua pihak yang ada baik di lingkungan sekolah maupun diluar lingkungan sekolah dalam memberikan pelayanan jasa sesuai dengan profesinya.

\section{Faktor-faktor yang mempengaruhi Kemampuan Guru}

1) Tingkat pendidikan. Kemampuan dipengaruhi latar belakang pendidikan, pengalaman mengajar dan lamanya megajar.

2) Motivasi, merupakan daya pendorong yang dapat mengarahkan perilaku seseorang untuk mencapai tujuannya,

3) Pendidikan dan latihan. Seseorang bisa kompeten karea memiliki bakat, tetapi jika bakat tersebut tidak pernah diasah maka kompetensinya tidak akan berkembang.

4) Kepemimpinan Kepala Sekolah akan membuat anggota atau pegawainya mau melakukan sesuatu atau berperilaku sesuai dengan apa yang diharapkan.

5) Supervisi pengawas sekolah, dapat membantu guru guru menjadi lebih baik dalam pekerjaannya, membantu guru mengembangkan pengetahuan, pemahaman dan pedagogiknya.

6) Iklim sekolah. Interaksi yang terjadi dalam sekolah akan membentuk iklim sekolah (Suhartini, 2011: 44)

\section{Penilaian Ranah Sikap}

Naniek Sulistyawardani, dkk (2012: 135) menyebutkan instrumen yang sering digunakan untuk mengukur sikap biasanya juga disebut skala sikap. Skala sikap merupakan gambaran tentang kecenderungan perilaku atau reaksi seseorang terhadap objek atau stimulus yang datang padanya. Macam- macam skala sikap, yaitu skala numerik, skala deskriptif dan skala grafis.

\section{Ranah Penilaian Afektif}

Berdasarkan kurikulum 2013 penilaian sikap dilaksanakan melalui teknik observasi, penilaian diri, dan penilaian teman sejawat menggunakan instrumen berupa daftar cek atau skala penilaian yang dilengkapi rubrik, sedangkan cara jurnal ialah berupa catatan.

\section{In House Training}

Menurut Danim (2012: 40) In house training merupakan pelatihan yang dilaksanakan internal oleh kelompok kerja guru, sekolah atau tempat lain yang ditetapkan sebagai penyelenggaraan pelatihan yang dilakukan berdasar pada pemikiran bahwa sebagian kemampuan dalam meningkatkan kompetensi dan karier guru tidak harus dilakukan secara eksternal, namun secara internal oleh guru sebagai trainer.

\section{Fase In House Training}

Marwansyah (2012:170) menyebutkan bahwa in house training dilakukan melalui tiga fase, yaitu fase perencanaan, fase proses penyelenggaraan dan fase evaluasi.

\section{METODE PENELITIAN}

Penelitian ini menggunakan pendekatan Penelitian Tindakan Kelas (PTK), dengan model Kemis dan Mc Taggart. Suyadi (2013: 50-67) menyatakan tiap siklus terdiri dari perencanaan, pelaksanaan tindakan, observasi dan refleksi. Subjek penelitian ini adalah guru kelas yang berjumlah 10 orang. Guru kelas tersebut terdiri dari guru kelas 1 dan kelas 3 sebanyak 1 orang dan guru kelas 2, kelas 4 , kelas 5, kelas 6 sebanyak 2 orang. Indikator keberhasilan penerapan pelatihan model IHT adalah apabila skor aktivitas trainer mencapai kategori baik. Sedangkan tingkat kemampuan guru ditandai dengan peningkatan kemampuan guru mulai dari siklus I dan II yaitu apabila prosentase guru yang memiliki nilai kemampuan dalam melakukan penilaian sikap kategori mampu telah mencapai $80 \%$, maka tindakan dinyatakan berhasil. 


\section{HASIL DAN PEMBAHASAN}

Hasil Penilaian observasi kemampuan guru dalam melakukan penilaian ranah sikap pada siklus I dirangkumkan sebagai berikut:

Tabel 1. Instrumen Observasi Kemampuan Guru Melakukan Penilaian Ranah Sikap Siklus I

\begin{tabular}{|c|c|c|c|c|c|c|c|c|c|c|c|c|}
\hline \multirow[t]{2}{*}{ No } & \multirow[t]{2}{*}{ Guru } & \multicolumn{2}{|c|}{$\begin{array}{l}\text { Penyusunan Kisi- } \\
\text { kisi }\end{array}$} & \multicolumn{2}{|r|}{$\begin{array}{l}\text { Penyusunan } \\
\text { Instrumen }\end{array}$} & \multicolumn{2}{|c|}{$\begin{array}{l}\text { Pelaksanaan } \\
\text { Penilaian } \\
\text { Sikap }\end{array}$} & \multicolumn{2}{|c|}{$\begin{array}{l}\text { Pengolahan } \\
\text { Penilaian } \\
\text { Sikap }\end{array}$} & \multicolumn{2}{|c|}{$\begin{array}{l}\text { Tindak } \\
\text { Lanjut }\end{array}$} & $\begin{array}{c}\text { Kemampuan } \\
\text { Guru }\end{array}$ \\
\hline & & Skor & Kriteria & Skor & Kriteria & Skor & Kriteria & Skor & Kriteria & Skor & Kriteria & Skor Kriteria \\
\hline 1 & R1 & 8 & $\begin{array}{l}\text { Sangat Kurang } \\
\text { Mampu }\end{array}$ & 8 & $\begin{array}{l}\text { Sangat Kurang } \\
\text { Mampu }\end{array}$ & 18 & $\begin{array}{l}\text { Cukup } \\
\text { Mampu }\end{array}$ & 9 & $\begin{array}{l}\text { Cukup } \\
\text { Mampu }\end{array}$ & 9 & $\begin{array}{l}\text { Cukup } \\
\text { Mampu }\end{array}$ & 52 Cukup \\
\hline 2 & R2 & 8 & $\begin{array}{c}\text { Sangat Kurang } \\
\text { Mampu }\end{array}$ & 11 & Cukup Mampu & 24 & $\begin{array}{l}\text { Sangat } \\
\text { Sangat } \\
\end{array}$ & 10 & Mampu & 10 & Mampu & 63 Mampu \\
\hline 3 & R3 & 8 & $\begin{array}{l}\text { Sangat Kurang } \\
\text { Mampu }\end{array}$ & 8 & $\begin{array}{c}\text { Sangat Kurang } \\
\text { Mampu }\end{array}$ & 18 & $\begin{array}{l}\text { Cukup } \\
\text { Mampu }\end{array}$ & 7 & $\begin{array}{l}\text { Kurang } \\
\text { Mampu }\end{array}$ & 6 & $\begin{array}{l}\text { Sangat } \\
\text { Kurang } \\
\text { Mampu }\end{array}$ & $\begin{array}{ll} & \text { Kurang } \\
\text { Mampu }\end{array}$ \\
\hline 4 & R4 & 12 & Cukup Mampu & 14 & Mampu & 24 & $\begin{array}{l}\text { Sangat } \\
\text { Mampu }\end{array}$ & 10 & Mampu & 8 & $\begin{array}{l}\text { Cukup } \\
\text { Mampu }\end{array}$ & 68 Mampu \\
\hline 5 & R5 & 12 & Cukup Mampu & 11 & Cukup Mampu & 24 & $\begin{array}{l}\text { Sangat } \\
\text { Mampu }\end{array}$ & 10 & Mampu & 10 & Mampu & 67 Mampu \\
\hline 6 & R6 & 16 & Sangat Mampu & 8 & $\begin{array}{c}\text { Sangat Kurang } \\
\text { Mampu }\end{array}$ & 24 & $\begin{array}{l}\text { Sangat } \\
\text { Mampu }\end{array}$ & 6 & $\begin{array}{l}\text { Sangat } \\
\text { Kurang } \\
\text { Mampu }\end{array}$ & 7 & $\begin{array}{l}\text { Kurang } \\
\text { Mampu }\end{array}$ & $61 \mathrm{Mampu}$ \\
\hline 7 & R7 & 9 & Kurang Mampu & 9 & $\begin{array}{l}\text { Kurang } \\
\text { Mampu }\end{array}$ & 24 & $\begin{array}{l}\text { Sangat } \\
\text { Mampu }\end{array}$ & 9 & $\begin{array}{l}\text { Cukup } \\
\text { Mampu }\end{array}$ & 8 & $\begin{array}{c}\text { Cukup } \\
\text { Mampu }\end{array}$ & $\begin{array}{cc}59 & \begin{array}{c}\text { Cukup } \\
\text { Mampu }\end{array} \\
\end{array}$ \\
\hline 8 & R8 & 9 & Kurang Mampu & 9 & $\begin{array}{l}\text { Kurang } \\
\text { Mampu }\end{array}$ & 24 & $\begin{array}{l}\text { Sangat } \\
\text { Mampu }\end{array}$ & 9 & $\begin{array}{l}\text { Cukup } \\
\text { Mampu }\end{array}$ & 8 & $\begin{array}{l}\text { Cukup } \\
\text { Mampu }\end{array}$ & $59 \begin{array}{c}\text { Cukup } \\
\text { Mampu }\end{array}$ \\
\hline 9 & R9 & 13 & Mampu & 10 & Cukup I & 18 & $\begin{array}{l}\text { Cukup } \\
\text { Mampu }\end{array}$ & 9 & $\begin{array}{l}\text { Cukup } \\
\text { Mampu }\end{array}$ & 8 & $\begin{array}{l}\text { Cukup } \\
\text { Mampu }\end{array}$ & $58 \begin{array}{c}\text { Cukup } \\
\text { Mampu }\end{array}$ \\
\hline 10 & R10 & 11 & Cukup Mampu & 10 & Cukup Mampu & 16 & $\begin{array}{l}\text { Cukup } \\
\text { Mampu }\end{array}$ & 7 & $\begin{array}{l}\text { Kurang } \\
\text { Mampu }\end{array}$ & 8 & $\begin{array}{l}\text { Cukup } \\
\text { Mampu }\end{array}$ & $\begin{array}{cc}52 & \begin{array}{c}\text { Cukup } \\
\text { Mampu }\end{array} \\
\end{array}$ \\
\hline
\end{tabular}

a) Sebagian besar guru kurang mampu menyusun kisi-kisi penilaian ranah sikap. Beberapa guru kadang tidak melakukan penyusunan kisi-kisi berdasarkan sikap spiritual dan sosial.

b) Sebagian besar guru cukup mampu dalam melakukan penyusunan instrumen. Terdapat temuan dimana masih terdapat guru yang tidak memberikan skor inventori pada instrument yang telah dibuat.

c) Proses pelaksanaan penilaian sikap mayoritas sangat mampu. Terdapat beberapa guru yang kadang tidak menilai sikap siswa berdasarkan kedisiplinan dan kepercayaan diri. d) Kemampuan guru melakukan pengolahan penilaian sikap pada kategori cukup mampu. Masih ada guru yang kadang tidak menandai catatan sikap peserta yang ditulis, membuat rekapitulasi berdasarkan kurikulum dan menyimpulkan catatan sikap peserta didik.

e) Tahap tindak lanjut mayoritas guru memiliki kemampuan cukup baik, terdapat beberapa guru melakukan program pembelajaran remedial untuk memperbaiki penilaian.

f) Kemampuan guru dalam melakukan penilaian ranah sikap $50 \%$ berada dalam kategori cukup mampu dan $10 \%$ guru yang kurang mampu. Penilaian terendah 
yang menunjukkan kemampuan guru sangat kurang mampu berada pada kategori penyusunan kisi-kisi. Hal tersebut dikarenakan guru masih bingung dalam melakukan penyusunan kisi-kisi yang sesuai dengan kurikulum.
Sedangkan penilaian observasi kemampuan guru dalam melakukan penilaian ranah sikap setelah dilaksanakan IHT dirangkumkan sebagai berikut:

Tabel 2. Instrumen Observasi Kemampuan Guru

Melakukan Penilaian Ranah Sikap Siklus II

\begin{tabular}{|c|c|c|c|c|c|c|c|c|c|c|c|c|c|}
\hline \multirow{2}{*}{\multicolumn{2}{|c|}{ No Guru }} & \multicolumn{2}{|c|}{$\begin{array}{c}\text { Penyusunan } \\
\text { Kisi-Kisi }\end{array}$} & \multicolumn{2}{|c|}{$\begin{array}{l}\text { Penyusunan } \\
\text { Instrumen }\end{array}$} & \multicolumn{2}{|c|}{$\begin{array}{l}\text { Pelaksanaan } \\
\text { Penilaian } \\
\text { Sikap }\end{array}$} & \multicolumn{2}{|c|}{$\begin{array}{l}\text { Pengolahan } \\
\text { Penilaian } \\
\text { Sikap }\end{array}$} & \multicolumn{2}{|c|}{ Tindak Lanjut } & \multicolumn{2}{|c|}{$\begin{array}{c}\text { Kemampuan } \\
\text { Guru }\end{array}$} \\
\hline & & Skor & Kriteria & Skor & Kriteria & Skor & Kriteria & Skor & Kriteria & Skor & Kriteria & Skor & Kriteria \\
\hline 1 & R1 & 14 & Mampu & 14 & Mampu & 24 & $\begin{array}{l}\text { Sangat } \\
\text { Mampu }\end{array}$ & 11 & $\begin{array}{l}\text { Sangat } \\
\text { Mampu }\end{array}$ & 9 & $\begin{array}{l}\text { Cukup } \\
\text { Mampu }\end{array}$ & 72 & Mampu \\
\hline 2 & R2 & 14 & Mampu & 14 & Mampu & 24 & $\begin{array}{l}\text { Sangat } \\
\text { Mampu }\end{array}$ & 11 & $\begin{array}{l}\text { Sangat } \\
\text { Mampu }\end{array}$ & 10 & Mampu & 73 & $\begin{array}{l}\text { Sangat } \\
\text { Mampu }\end{array}$ \\
\hline 3 & R3 & 14 & Mampu & 14 & Mampu & 24 & $\begin{array}{l}\text { Sangat } \\
\text { Mampu }\end{array}$ & 11 & $\begin{array}{l}\text { Sangat } \\
\text { Mampu }\end{array}$ & 9 & $\begin{array}{l}\text { Cukup } \\
\text { Mampu }\end{array}$ & 72 & Mampu \\
\hline 4 & R4 & 15 & $\begin{array}{l}\text { Sangat } \\
\text { Mampu }\end{array}$ & 15 & $\begin{array}{l}\text { Sangat } \\
\text { Mampu }\end{array}$ & 24 & $\begin{array}{l}\text { Sangat } \\
\text { Mampu }\end{array}$ & 11 & $\begin{array}{l}\text { Sangat } \\
\text { Mampu }\end{array}$ & 10 & Mampu & 75 & $\begin{array}{l}\text { Sangat } \\
\text { Mampu }\end{array}$ \\
\hline 5 & R5 & 16 & $\begin{array}{l}\text { Sangat } \\
\text { Mampu }\end{array}$ & 14 & Mampu & 24 & $\begin{array}{l}\text { Sangat } \\
\text { Mampu }\end{array}$ & 11 & $\begin{array}{l}\text { Sangat } \\
\text { Mampu }\end{array}$ & 10 & Mampu & 75 & $\begin{array}{l}\text { Sangat } \\
\text { Mampu }\end{array}$ \\
\hline 6 & R6 & 16 & $\begin{array}{l}\text { Sangat } \\
\text { Mampu }\end{array}$ & 14 & Mampu & 24 & $\begin{array}{l}\text { Sangat } \\
\text { Mampu }\end{array}$ & 10 & Mampu & 10 & Mampu & 74 & $\begin{array}{r}\text { Sangat } \\
\text { Mampu }\end{array}$ \\
\hline 7 & R7 & 14 & Mampu & 14 & Mampu & 24 & $\begin{array}{l}\text { Sangat } \\
\text { Mampu }\end{array}$ & 10 & Mampu & 10 & Mampu & 72 & Mampu \\
\hline 8 & R8 & 14 & Mampu & 14 & Mampu & 24 & $\begin{array}{l}\text { Sangat } \\
\text { Mampu }\end{array}$ & 11 & $\begin{array}{l}\text { Sangat } \\
\text { Mampu }\end{array}$ & 10 & Mampu & 73 & $\begin{array}{r}\text { Sangat } \\
\text { Mampu }\end{array}$ \\
\hline 9 & R9 & 15 & $\begin{array}{l}\text { Sangat } \\
\text { Mampu }\end{array}$ & 14 & Mampu & 24 & $\begin{array}{l}\text { Sangat } \\
\text { Mampu }\end{array}$ & 10 & Mampu & 10 & Mampu & 73 & $\begin{array}{l}\text { Sangat } \\
\text { Mampu }\end{array}$ \\
\hline 10 & R10 & 14 & Mampu & 14 & Mampu & 24 & $\begin{array}{l}\text { Sangat } \\
\text { Mampu }\end{array}$ & 11 & $\begin{array}{l}\text { Sangat } \\
\text { Mampu }\end{array}$ & 10 & Mampu & 73 & $\begin{array}{l}\text { Sangat } \\
\text { Mampu }\end{array}$ \\
\hline
\end{tabular}

1) Sebagian besar guru mampu menyusun kisi-kisi penilaian ranah sikap. Setelah dilakukan pelatihan, semua guru diketahui menyusun kisi-kisi penilaian ranah sikap berdasarkan sikap sipiritual dan mengacu pada kurikulum. Guru juga menyusun kisi-kisi berdasarkan sikap social dan menentukan indikator penilaian sesuai dengan kompetensi sikap yang akan di kembangkan.

2) Mayoritas guru mampu melakukan penyusunan instrument sesuai teknik yang digunakan dan meningkatkan kemampuan guru memberikan skor inventori pada instrument yang telah dibuat.
3) Proses pelaksanaan penilaian sikap mayoritas dalam kategori sangat mampu. Guru mampu melaksanakan penilaian berdasarkan sikap spiritual dan kejujuran siswa, tanggung jawab siswa, toleransi siswa, dan sopan santun siswa.

4) Kemampuan guru melakukan kegiatan pengolahan penilaian sikap berada pada kategori sangat mampu. Sebagian besar guru menguasai kegiatan pengolahan penilaian sikap dengan menandai catatan sikap peserta didik, rekapitulasi sikap, mengumpulkan dan menyimpulkan catatan capaian sikap peserta didik.

5) Pada tahap tindak lanjut mayoritas guru mampu melaksanakan kegiatan tindak 
lanjut. Meskipun sebagian besar guru tidak selalu melakukan program pembelajaran remidial, program pengayaan dan membuat grafik perkembangan.

6) Kemampuan guru dalam melakukan penilaian $70 \%$ berada dalam kategori sangat mampu dan 30\% guru yang mampu. Guru sudah memahami dan mempraktikkan penyusunan kisi-kisi dan penyusunan instrument sesuai kurikulum, melaksanakan penilaian sikap dan pengolahan penilaian sikap berdasarkan kurikulum, dan mampu melakukan program tindak lanjut pembelajaran untuk meningkatkan kemampuan siswa.

In house training merupakan kegiatan pelatihan yang dilaksanakan oleh kelompok kerja guru, sekolah atau tempat lain untuk penyelenggaraan pelatihan guna meningkatkan kompetensi dan karier guru (Danim, 2012: 40). Melalui pelatihan model IHT, guru dapat mengasah kemampuan secara aktif dengan mengeksplorasi materi pelatihan secara konsisten, persisten dan mengarah pada tujuan yang ingin dicapai.

Salah satu faktor yang melatarbelakangi pelaksanaan IHT di SD Negeri Canden ialah kemampuan guru dalam melakukan penilaian sikap terhadap peserta didik yang cenderung kurang. Langkah pelatihan model IHT merupakan factor penyebab keberhasilan pelatihan, hal ini terlihat dari aktivitas yang dilakukan pada setiap langkah IHT, terutama langkah-langkah pada fase proses penyelenggaraan IHT.

Baik pada siklus I maupun siklus II, sebanyak 10 orang (100\%) guru menyatakan bahwa trainer mampu melaksanakan kegiatan pendahuluan dengan baik. Pada tahap inti, trainer diharuskan membagi peserta menjadi 3 kelompok, memberikan instruksi kepada peserta untuk membaca materi kompetensi dasar dalam silabus kurikulum SD tahun 2013, mendorong peserta membaca materi, membimbing peserta melakukan diskusi kelompok untuk menganalisis ranah kompetensi pembelajaran yang ditetapkan dalam silabus, membimbing peserta melakukan diskusi kelompok untuk menganalisis ranah kompetensi pembelajaran yang ditetapkan dalam silabus, membangun suasana IHT yang akrab dan menyenangkan dan memberikan kesempatan kepada kelompok untuk bertanya tentang materi yang belum difahami/ dimengerti.

Hasil observasi pada siklus I menunjukkan trainer cukup mampu mengelompokkan peserta mempelajari materi penilaian sesuai kurikulum, namun kemampuan trainer menciptakan suasana pelatihan yang menyenangkan masih kurang optimal. Sedangkan pada siklus II, trainer sudah mampu mengelompokkan peserta agar mempelajari materi penilaian sesuai kurikulum. Hal ini menunjukkan bahwa trainer mampu memperbaiki kekurangan dalam memberikan pelatihan sesuai kekurangan dengan membangun suasana pelatihan yang lebih akrab dan memberikan bimbingan lebih intens kepada guru untuk meningkatkan motivasi guru mengikuti kegiatan IHT yang diakhiri dengan pembuatan penilaian ranah sikap oleh guru.

Peningkatan ketercapaian kemampuan aktivitas trainer selama penelitian tindakan sekolah siklus I dan siklus II untuk lebih jelasnya ditampilkan pada gambar 1 berikut:

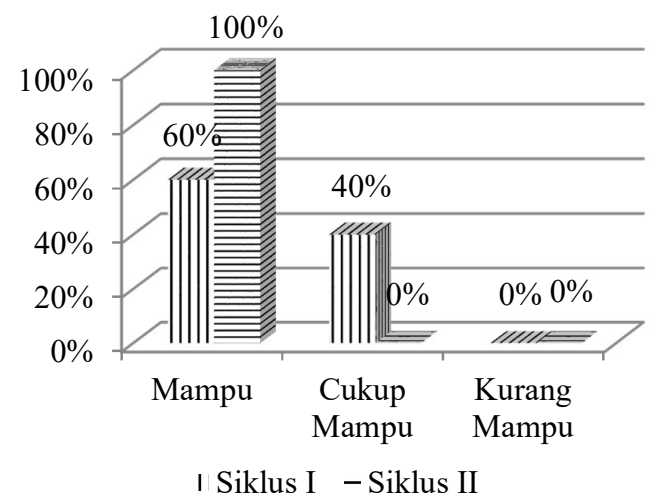

Gambar 1. Tingkat Ketercapaian Aktivitas Trainer Siklus I dan II 
Berdasarkan gambar 1 diketahui aktivitas trainer dalam memberikan pelatihan penilaian ranah sikap terhadap guru telah terlaksana dengan baik, dimana terdapat peningkatan aktivitas trainer dari siklus I ke siklus II. Jika dikaitkan dengan kriteria keberhasilan PTS dengan indikator pelatihan IHT dikatakan berhasil apabila skor aktivitas trainer dalam memberikan pelatihan mencapai $80 \%$, maka dapat dikatakan bahwa PTS siklus I dan II telah berhasil.

Keberhasilan aktivitas trainer dalam memberikan pelatihan ditunjukkan dengan adanya peningkatan skor pada proses inti sebanyak $70 \%$ pada kategori cukup mampu menjadi mampu pada siklus II dan pada proses penutupan yang semula $70 \%$ berada pada kategori kurang mampu menjadi mampu (60\%) dan cukup mampu (40\%) pada siklus II. Keefektifan langkah-langkah IHT yang dilakukan peneliti telah sejalan dengan pandangan Marwansyah (2012:170) yang menjelaskan bahwa in house training dilakukan melalui tiga fase, yaitu fase perencanaan, penyelenggaraan dan penilaian.

Keberhasilan aktivitas trainer juga ditunjukkan oleh adanya peningkatan respon guru terhadap pelaksanaan IHT yang pada siklus I tingkat motivasi dinilai kurang baik (30\%) menjadi cukup baik (90\%) pada siklus II, dan tingkat bimbingan yang kurang baik (40\%) menjadi baik (10\%) pada siklus II. Selain itu, tingkat kehadiran dan kedisiplinan guru yang kurang baik $(90 \%)$ pada siklus I menjadi baik (100\%) pada siklus II. Hal ini menunjukkan kemampuan trainer dalam memberikan pelatihan telah berjalan dengan baik, dimana trainer mulai dapat meningkat motivasi guru mengikuti kegiatan pelatihan dengan aktif pada siklus II dan trainer juga diketahui mampu meningkatkan kegiatan bimbingan menjadi baik pada siklus II.

Peningkatan keberhasilan aktivitas trainer dalam memberikan pelatihan berdampak pada keberhasilan peningkatan kemampuan guru melakukan penilaian ranah sikap. Setiap orang bisa kompeten karena memiliki bakat, tetapi jika bakat tersebut tidak pernah diasah maka kompetensinya tidak akan berkembang. Guru yang sering mendapat pelatihan dan hasil pelatihan tersebut dikembangkan dan diaplikasikan dalam pekerjaannya, maka kemampuanya akan berkambang dan meningkat. Hal ini dibuktikan dengan peningkatan nilai kemampuan guru antar siklus yang ditunjukkan pada table 3 berikut:

Tabel 3. Ketercapaian Kemampuan Guru dalam Melakukan Penilaian Ranah Sikap

\begin{tabular}{|c|c|c|c|}
\hline \multirow[t]{2}{*}{ No } & \multirow[t]{2}{*}{ Kategori } & \multicolumn{2}{|c|}{$\begin{array}{c}\text { Perbandingan Tingkat } \\
\text { Ketercapaian }\end{array}$} \\
\hline & & Siklus I & Siklus II \\
\hline & $\begin{array}{l}\text { Penyusunan } \\
\text { Kisi-Kisi }\end{array}$ & \multirow{5}{*}{$\begin{array}{l}50 \% \\
\text { Cukup } \\
\text { Mampu }\end{array}$} & \multirow{5}{*}{$\begin{array}{c}70 \% \\
\text { Sangat } \\
\text { Mampu }\end{array}$} \\
\hline 2. & $\begin{array}{l}\text { Penyusunan } \\
\text { Instrumen }\end{array}$ & & \\
\hline 3. & $\begin{array}{l}\text { Pelaksanaan } \\
\text { Penilaian Sikap }\end{array}$ & & \\
\hline 4. & $\begin{array}{l}\text { Pengolahan } \\
\text { Penilain Sikap }\end{array}$ & & \\
\hline \multirow[t]{2}{*}{5.} & Tindak Lanjut & & \\
\hline & $\begin{array}{cc}\text { Hasil } & \text { peneliti } \\
\text { pat } & \text { peningl }\end{array}$ & $\begin{array}{l}\text { an diket } \\
\text { ratan }\end{array}$ & $\begin{array}{l}\text { hui bahwa } \\
\text { ketercapaian }\end{array}$ \\
\hline \multicolumn{4}{|c|}{$\begin{array}{l}\text { terdapat peningkatan ketercapaian } \\
\text { kemampuan guru dalam melakukan penilaian } \\
\text { ranah sikap, dimana pada siklus kemampuan } \\
\text { guru berada pada kategori cukup mampu } \\
\text { sebesar } 50 \% \text { menjadi sangat mampu sebesar } \\
70 \% \text { pada siklus II. Peningkatan ketercapaian } \\
\text { kemampuan guru secara rinci dapat dilihat } \\
\text { pada gambar berikut: }\end{array}$} \\
\hline
\end{tabular}

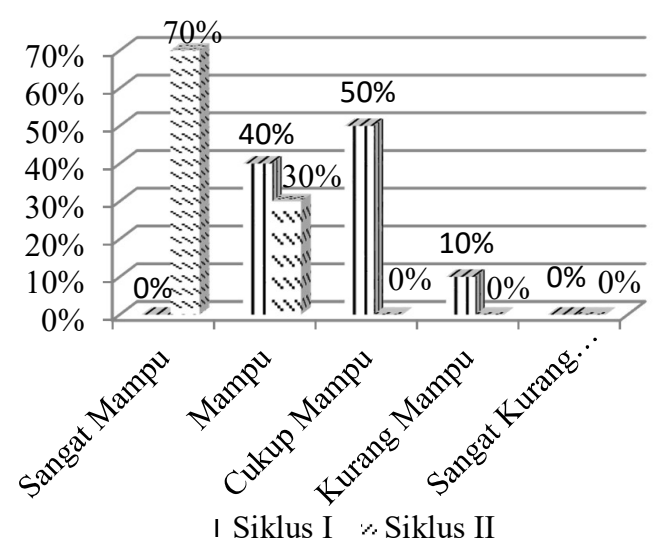

Gambar 2. Tingkat Ketercapaian Kemampuan Guru Siklus I dan II 
Berdasarkan gambar tersebut diketahui bahwa kemampuan guru dalam melakukan penilaian ranah sikap setelah diadakannya pelatihan dengan metode IHT menunjukkan adanya peningkatan. Kemampuan yang meningkat berkaitan dengan pemahaman konsep mengenai kemampuan menyusun kisikisi, kemampuan menyusun instrument, kemampuan melaksanakan penilaian sikap, pengolahan penilaian sikap dan kemampuan melakukan tindak lanjut pembelajaran.

Temuan tersebut mendukung penelitian yang dilakukan Suhandi Astuti (2016: 6) bahwa pelatihan model in house training dapat meningkatkan kemampuan guru dalam menyusun instrument penilaian ranah sikap. Kontribusi penelitian secara teoritis memantapkan langkah-langkah penyusunan skala sikap model likert, dan secara praktik meningkatkan kemampuan guru dalam menyusun instrument penilaian ranah sikap dalam pembelajaran.

Pada siklus I, terdapat $30 \%$ guru yang memiliki kemampuan penyusunan kisi-kisi pada kategori sangat kurang mampu dan $20 \%$ kurang mampu. Pada tahap penyusunan instrument, sebanyak 30\% guru memiliki kemampuan sangat kurnag mampu dan 20\% kurang mampu, pada tahap pelaksanaan penilaian sikap mmayoritas guru $(60 \%)$ guru diketahui sangat mampu melaksanakan penilaian. Sedangkan pada tahap pengolahan penilaian sikap terdapat $10 \%$ guru yang sangat kurang mampu dan $20 \%$ kurang mampu, dan terakhir pada tahap tindak lanjut sebagian besar guru (60\%) diketahui sudah cukup mampu melakukan tindak lanjut, meskipun demikian masih terdapat $10 \%$ guru yang memiliki kemampuan pada kategori sangat kurang mampu.

Hasil observasi pada siklus I menunjukkan penilaian kemampuan guru di SD N Canden dalam melakukan penilaian ranah sikap melalui in house training pada kategori cukup, karena itu perlu dilaksanakan siklus II untuk mencapai kemampuan yang lebih baik dengan memberikan bimbingan dan motivasi kepada guru tentang penyusunan kisi-kisi pembelajaran yang sesuai dengan kurikulum, memberikan tambahan pengetahuan tentang pelaksanaan penilaian ranah sikap berdasarkan kurikulum acuan yaitu kurikulum 2013 untuk meningkatkan ketrampilan dalam menyusun penilaian ranah sikap yang lebih efektif, dan memberikan bimbingan kepada guru tentang cara melakukan penilaian yang tepat dengan mengacu pada indikator dan langkah penilaian yang tepat sesuai kurikulum 2013.

Setelah dilakukan bimbingan lebih intens, hasil observasi pada siklus II menunjukkan peningkatan dengan hasil sebagai berikut: kemampuan penyusunan kisikisi guru meningkat menjadi mampu sebesar $60 \%$ dan $40 \%$ lainnya menjadi sangat mampu; pada kegiatan penyusunan isntrumen sebanyak $90 \%$ guru memiliki kemampuan dengan kategori mampu dan 10\% pada kategori sangat mampu; pada pelaksanan penilaian sikap semua guru (100\%) memiiki kemampuan dengan kategori sangat mampu; sedangkan pada pengolahan penilaian sikap mayoritas guru (70\%) memiliki kemampuan sangat mampu dan $30 \%$ lainnya pada kategori mampu dan pada tindak lanjut meskipun sebagian besar guru (80\%) memiliki kemampuan pada kategori mampu, namun $20 \%$ lainnya pada kategori cukup mampu.

Kemampuan guru berkaitan dengan pengetahuan, keterampilan dan sikap yang ditampilkan dalam bentuk perilaku cerdas dan penuh tanggung jawab yang dimiliki dalam menjalankan profesinya. Secara keseluruhan, kemampuan guru dalam melakukan penilaian ranah sikap mengalami peningkatan menjadi sangat mampu sebanyak $70 \%$, dan mampu sebanyak $30 \%$. Masih perlu adanya pelatihan yang lebih optimal untuk meningkatkan kemampuan guru yang berada pada kategori mampu agar dapat menyusul kemampuan guru lainnya yang sudah memiliki kemampuan pada kategori sangat mampu. 
Melalui pelatihan yang dilakukan secara berkala baik dengan metode In House Training maupun metode lainnya dapat membantu guru dalam meningkatkan kemampuannya lebih optimal, karena guru akan lebih memahami dan menguasai program belajar mengajar yang dilakukan. Guru juga akan menguasai bahan ajar dan kegiatan penilaian terhadap bidang studi yang dipegang. Sejalan dengan penelitian Astuti (2017: 41) yang menunjukkan hal serupa, dimana pelaksanaan in house training dapat meningkatkan kemampuan guru dalam menyusun instrumen ranah sikap dibuktikan dengan keberhasilan sebesar 76,92\% pada siklus I menjadi $80 \%$ pada siklus II.

Berdasarkan hasil dan pembahasan di atas pelatihan metode in house training mampu meningkatkan kemampuan guru dalam melakukan penilaian ranah sikap secara optimal. Dengan In House Training ini, Guru lebih mendapatkan pembimbingan secara langung dalam membuat perlengkapan penilaian mengajar dan menerima penyajian materi untuk menambah wawasan mereka. Selain itu, melalui In House training ini Guru dapat berbagi dengan Guru lainnya dalam hal kesulitan yang mereka hadapi dalam membuat perlengkapan penilaian mengajar.

\section{KESIMPULAN}

Penerapan in house training di SD N Canden Tahun Pelajaran 2018/2019 dilakukan melalui tiga fase, yaitu fase pendahuluan, inti dan penutup. Kemampuan trainer dalam menerapkan in house training pada siklus I berada pada kategori mampu sebayak $60 \%$ dan meningkat menjadi $100 \%$ pada siklus II. Model pelatihan in house training mampu meningkatkan kemampuan guru dalam melakukan penilaian ranah sikap. Hal ini dibuktikan dengan peningkatan kemampuan guru pada siklus I sebesar 50\% dengan kategori cukup mampu menjadi sangat mampu sebesar $70 \%$ dan mampu sebesar $30 \%$ pada siklus II.

\section{DAFTAR PUSTAKA}

Alufohai and Ainlosotu. (2016). Knowledge and Attitude of Secondary School Teachers Towards Continuous Assessment Practices in Esan Central Senatorial District of Edo State. Journal of Education and Practice ISSN 22221735 (Paper) ISSN 2222-288X (Online) Vol.7, No.10, 2016.

Astuti, Slameto dan Dwikurnaningsih. (2017). Peningkatan Kemampuan Guru Sekolah Dasar Dalam Penyusunan Instrumen Ranah Sikap Melalui In House Training. Jurnal Manajemen Pendidikan Volume: 4, No. 1, JanuariJuni 2017.

Astuti, Suhandi. 2017. In House Training Untuk Meningkatkan Kemampuan Guru SD Dalam Penyusunan Instrumen Penilaian Ranah Sikap. Tesis: Universitas Kristen Satya Wacana.

Blazar and Kraft. 2017. Teacher and Teaching Effect on Students' Attitudes and Behaviors. Journal Educ Eval Policy Anal 2017 Mar 39 (1) 146-170.

Danim, Sudarwan. 2011. Pengembangan Profesi Guru. Jakarta: Kencana Prenada Media Group.

Danim, Sudarwan. 2012. Motivasi Kepemimpinan dan Efektivitas Kelompok. Jakarta: Rineka Cipta.

Dasman. 2016. Peningkatan Kemampuan Guru Dalam Menyusun Kelengkapan Mengajar Melalui In-House Training Di SMPN 4 Pasaman. Jurnal Manajemen Pendidikan Vol. I No.1 Th. 2016.

Departemen Pendidikan Nasional Peraturan Pemerintah nomor 32 tahun 2013 tentang Standar Nasional Pendidikan.

Marwansyah. 2012. Manajemen Sumber Daya Manusia. Bandung: Alfabeta.

Suhartini, Entin. 2011. Analisis Faktor-Faktor yang Mempengaruhi Kompetensi Guru pada Sekolah Menengah Kejuruan Rintisan Sekolah Bertaraf Internasional di Kabupaten Indramayu. Tesis: Universitas Indonesia.

Sulistyawardani, Naniek dkk. 2012. Asesmen Pembelajaran Bahan Belajar Mandiri SD. Salatiga: Widya Sari Press Salatiga.

Suyadi. 2013. Strategi Pembelajaran Pendidikan Karakter. Bandung: Remaja Rosdakarya. 